\title{
PENGARUH SUMBER DAYA MANUSIA TERHADAP KINERJA PEGAWAI PADA DINAS PENDIDIKAN KABUPATEN LAMPUNG BARAT
}

\author{
Oleh: \\ Melan Susanty Purnamasari ${ }^{1}$ \\ Asroni $^{2}$ \\ Program Studi Administrasi Bisnis FISIP Universitas Tulang Bawang Lampung \\ e-Mail: melan.susanty@utb.ac.id
}

\begin{abstract}
ABSTRAK
Keberhasilan utama suatu organisasi dalam pencapaian hasil yang optimal dibutuhkan tenagatenaga sumber daya manusia yang benar-benar terampil dan mau memperlihatkan kinerja secara baik pula. Menyadari akan hal tersebut diatas maka sumber daya manusia (pegawai) dalam melaksanakan kewajiban-kewajibannya dalam proses pekerjaan harus mampu melaksanakan tugas dan fungsinya secara sadar, bertanggung jawab dan mempunyai disiplin yang tinggi. Penelitian ini menganalisis tentang pengaruh sumber daya manusia terhadap kinerja pegawai pada dinas Pendidikan Kabupaten Lampung Barat. Tujuan penelitian ini adalah yaitu untuk mengetahui kualitas sumber daya manusia terhadap kinerja pegawai pada Dinas Pendidikan Kabupaten Lampung Barat, dengan metode penelitian secara deskriptif. Teknik pengumpulan data yaitu dengan mengadakan studi kepustakaan dan mangadakan studi lapangan, dan menghimpun secara langsung dari responden. Berdasarkan hasil analisa jawaban dari kuesioner, wawancara pada pegawai Dinas Pendidikan Kabupaten Lampung Barat dapat disimpulkan bahwa kualitas sumber daya manusia mempunyai pengaruh yang signifikan terhadap kinerja pegawai pada Dinas Pendidikan Kabupaten Lampung Barat.
\end{abstract}

Kata kunci: pengaruh; kinerja; sumber daya manusia; pegawai

\section{PENDAHULUAN}

Pendidikan dianggap sebagai suatu investasi yang paling berharga dalam bentuk peningkatan sumber daya insani untuk pembangunan suatu bangsa. Kualitas pendidikan tidak saja terlihat dari kemegahan fasilitas pendidikan yang dimiliki tetapi sejauh mana suatu pendidikan dapat membangun tahapan pendidikan tersebut.
Pembangunan sektor pendidikan sejak semula memang diarahkan untuk menjadi tanggung jawab antara pemerintah dan masyarakat.

Undang-Undang Nomor 20 Tahun 2003 tentang Sistem Pendidikan Nasional disebutkan bahwa, hak dan kewajiban warga negara, orang tua, masyarakat dan pemerintah. Selanjutnya Pemerintah dan Pemerintah Daerah berhak mengarahkan, 
membimbing, membantu, dan mengawasi penyelenggaraan pendidikan sesuai dengan peraturan perundang-undangan yang berlaku serta wajib memberikan Isyanan dan kemudahan serta menjamin terselenggaranya pendidikan yang bermutu bagi setiap warga negara tanpa diskriminasi.

Dengan demikian keberhasilan proses penyelenggaraan pendidikan dalam rangka menghasilkan sumber daya manusia Indonesia yang berkualitas, akan ditentukan banyak faktor diantaranya instansi pemerintah yang dalam hal ini adalh dinas pendidikan. Berbicara tentang pendidikan tentu tidak lepas dari peran pimpinan dan bawahannya atau pegawai yang merupakan personil yang bekerja pada Dinas Pendidikan.

Untuk itu pentingnya ada upaya perbaikan ataupun pembaharuan suasana dalam menggerakkan pegawai agar dapat berprestasi dalam bekerja. Faktor pengembangan kerja pegawai agar dapat diabaikan dalam rangka meningkatkan kinerja pegawai, ini menjadi prioritas usaha mengingat masih banyaknya kemempuan pegawai mengenai bidang pekerjaan masih sangat terbatas, masih kurangnya pengetahuan dan keterampilan pegawai terhadap pekerjaan ataupun bidang pekerjaan yang tidak sesuai dengan latar belakang pendidikannya. Apabila masalah ini dibiarkan saja tanpa mencari terobosanterobosan untuk perbaikan, tidak menutup kemungkinan akan menurunnya kinerja pegawai di dunia pendidikan itu sendiri.

Lembaga atau instansi pemerintah senantiasa mengikuti perkembangan dan pertumbuhan sumber daya manusia yang ada ditandai dengan makin besarnya verifikasi tenaga kerja, bentuk organisasi dan persaingan global yang terus meningkat. Upaya pengembangan memungkinkan pegawai untuk memperluas kewajiban serta tanggung jawab yang lebih besar.

Pengembangan sumber daya manusia merupakan perencanaan usaha berlanjut oleh manajemen untuk meningkatkan kemampuan karyawan dalam mengukur dan mencapai organisasi melalui program pelatihan, pengembangan dan pendidikan.

Pengembangan pegawai hendaknya dirasakan semakin penting manfaatnya karena tuntutan pekerjaan atau jabatan. Pengembangan adalah suatu usaha untuk meningkatkan kemampuan teknis, teoritis, konseptual dan moral pegawai sesuai dengan kebutuhan pekerjaan atau jabatan melalui pendidikan dan latihan. Pimpinan semakin menyadari pegawai baru pada umumnya hanya mempunyai kecakapan teoritis saja dari lembaga pendidikan, agar pengembangan sumber daya manusia dapat berjalan sesuai dengan rencana dan mencapai tujuan yang diinginkan, langkah-langkah yang harus dilakukan adalah penilaian kebutuhan. Tujuan pengembangan harus dapat memenuhi kebutuhan, materi program berdasarkan keahlian, dan prinsip pembelajaran yang dibutuhkan.

Melihat arah kedepan pengembangan sumber daya manusia, maka prinsip pembelajaran merupakan pedoman dimana proses belajar akan berjalan lebih efektif karena mengandung unsur partisipasi, pengulangan, relevansi, pengalihan dan umpan balik.

Disamping itu pula pegawai menunjukkan sikap yang didasari pada penilaian pekerjaannya. Kepuasan kerja pegawai merupakan sikap spesifik terhadap suatu objek yang dimiliki oleh pegawai dan objek dari sikap itu diungkapkan dalam respon efektif berupa perasaan senang maupun tidak 
senang terhadap pekerjaan tersebut. Jadi kepuasan kerja seseorang pegawai dalam bekerja dapat diketahui melalui sikap pegawai terhadap lingkungan kerja, lingkungan fisik, lingkungan psikis maupun lingkungan sosialnya sendiri. Sikap positif menunjukkan kesesuaian antara keinginan yang akan dicapai dengan apa yang diperoleh, sedangkan sikap negatif menunjukkan suatu indikasi ketidak sesuaian anatar apa yang diharapkan dengan apa yang diperoleh dan pada akhirnya akan menimbulkan ketidak puasan pada diri pegawai.

Kebutuhan yang dimiliki oleh pegawai sebagai manusia cenderung tidak terbatas, artinya kebutuhan selalu bertambah dari waktu ke waktu dan selalu berusaha dengan segala kemampuan untuk memuaskan kebutuhan tersebut. Untuk itu pegawai terdorong untuk melakukan aktivitas yang disebut dengan kerja, meskipun tidak semua aktivitas dikatakan kerja.

Dengan demikian upaya meningkatkan sumber daya manusia di lingkungan Dinas Pendidikan akan berkembang sangan baik dan akan memberikan konsep kinerja dari kegiatan tertentu dan periode tertentu pula, seperti yang dikemukakan Wood Et al (2001:114), memberikan pengertian bahwa kinerja merupakan suatu pengukuran ringkas dari kualitas maupun kuantitas tugas-tugas yang dilakukan oleh individu atau pegawai untuk kerja unit atau dinas.

Sedangkan Mangkunegara (2008:67) mengemukakan bahwa yang dimaksud kinerja pegawai adalah hasil secara kualitas dan kuantitas yang dicapai oleh pegawai dan melaksanakan sesuai dengan tanggung jawab yang telah diberikan kepadanya, jadi jelas dalam kinerja pegawai sangat dipengaruhi oleh motivasi, kemampuan, dan kesempatan yang tersedia untuk melakukan pekerjaan tersebut.

Untuk menganalisa apa yang diuraikan diatas perlu penelitian yang lebih mendalam tentang Pengaruh Kualitas Sumber Daya Manusia terhadap Kinerja Pegawa pada Dinas Pendidikan Kabupaten Lampung Barat.

\section{TINJAUAN PUSTAKA}

Menurut Husein Umar (2005) sumber daya manusia adalah suatu perencanaan, pengorganisasian, pengarahan dan pengawasan atas pengembangan dan pengadaan, kompensasi pengintegrasian, pemeliharaan dan penuntasan hubungan kerja dengan maksud untuk mencapai tujuan secara terpadu.

Dalam Kamus Besar Indonesia (2002:1102) sumber daya manusia adalah tempat keluar atau asal daya manusia adalah potensi manusia yang dapat dikembangkan untuk proses produksi. Sumber daya manusia (SDM) adalah tempat keluar/asalnya potensi manusia yang dapat dikembangkan untuk proses produksi.

Dari pengertian diatas penulis menyimpulkan bahwa yang dimaksud sumber daya manusia adalah orang (pegawai) yang siap, mau dan mampu memberikan sumbangan pemikiran dan melaksanakan pekerjaan atau tugas dalam usaha mencapai tujuan organisasi the officers who are able to give opinion and conduct duties in achieiving the goals af organization).

Maka mengidentifikasikan dan mempelajari pegawai perlu dilakukan agar dapat diintegrasikan secara efektif dalam suatu 
instansi/dinas dalam rangka mencapai tujuan, karena dengan meningkatnya potensi sumber daya manusia dalam suatu instansi/dinas akan berdampak terhadap kinerja dalam pencapaian efektivitas bekerja sesuai dengan target yang diinginkan.

\section{METODOLOGI PENELITIAN}

Metode penelitian yang akan digunakan dalam penelitian ini adalah metode penelitian berbentuk deskriptif, yaitu penelitian yang bertujuan memberikan gambaran yang secermat mungkin mengenai suatu keadaan, gejala, individu atau kelompok lain.

Menurut Surakhmad (2004) mengatakan bahwa penelitian deskriptif adalah ditujukan pada pemecahan masalah yang ada pada masa sekarang. Penelitian ini merupakan penyelidikan yang menuturkan, menganalisa dan mengkiasifikasikan, penyelidikan dengan metode survey dengan teknik interview, angket, observasi atau teknik tes, studi kasus, studi komparatif, studi waktu dan gerak analisa kualitatif, studi kooperatif atau operasional.

Jadi jenis metode deskriptif adalah suatu metode yang menuturkan dan menafsirkan data yang ada, yang pelaksanaannya tidak terbatas pada pengumpulan data dan penyusunan data, tetapi meliputi analisis data, interprestasi tentang suatu data yang diteliti pada masa sekarang. Pengukuran variabel dilakukan untuk mengetahui instrumen yang akan digunakan dapat diukur sesuai dengan apa yang hendak diukur dan bisa dipercaya serta reliabel (konsisten) terhadap permasalahan instrumen penelitian, maka dalam penelitian ini akan digunakan skala pengukuran untuk mengklarifikasikan variabel yang akan diukur supaya tidak terjadi kesalahan dalam menetukan analisis data dan langkah penelitian selanjutnya.

Jenis skala pengukuran yang akan digunakan adaiah skala likert, yaitu skala sikap untuk mengukur sikap, perilaku, persepsi, pendapat, dan sebagainya dari objek atau individuindividu yang diteliti. Pengukuran ini dilakukan dengan menggunakan instrumen penelitian atau angket yang berisi daftar pertanyaan atau pernyataan dengan skala interval dari jawaban responden yang diajukan diberikan skor sebagai berikut:

Alternatif jawaban Sangat Setuju (SS) diberi skor 5;

Alternatif jawaban Setuju (S) diberi skor 4; Alternatif jawaban Netral (S) diberi skor 3; Alternatif jawaban Tidak Setuju (TS) diberi skor 2;

Alternatif jawaban Sangat Tidak Setuju (STS) diberi skor 1;

Untuk mengumpulkan data yang diperlukan penulis menggunakan atau menempuh cara sebagai berikut:

1. Untuk memperoleh data skunder, penulis mengadakan studi kepustakaan dengan cara membaca, mencatat/mengutip dari buku-buku atau referensi yang ada kaitannya dengan permasalahan yang sedang dibahas, dalam hal ini masalah kualitas sumber daya manusia dan kinerja pegawai.

2. Untuk mendapatkan data primer, penulis mangadakan studi lapangan, dan menghimpun secara langsung dari responden. Agar data yang didapat benar-benar data yang valid dan reliabel, maka prosedur pengumpulan data yang akan dilakukan peneliti dengan menggunakan teknik atau cara pengumpulan data melalui angket 
(kuesioner) sebagai instrumen pengumpulan data atau alat bantu dalam pengumpulan data.

Jenis angket (kuesioner) yang digunakan adalah angket terbuka atau angket tak berstruktur, menurut Riduwan (2004:99), angket terbuka adalah angket yang disajikan dalam bentuk sederhana sehingga responden dapat memberikan isian sesuai dengan kehendak dan keadaannya.

1. Populasi dan sampel

a. Populasi

Populasi adalah keseluruhan subyek dari penelitian. (Arikunto, 2006). Sedangkan menurut pendapat lain populasi adalah jumlah keseluruhan dari unit analisa yang cirinya akan diduga (Singarimbun, 2008). Dari dua pendapat diatas dapat ditarik kesimpulan, bahwa populasi adalah seluruh subyek yang menjadi sasaran dalam suatu penelitian.

Adapun yang menjadi populasi dalam penelitian ini adalah seluruh pegawai yang ada pada Dinas Pendidikan di Kabupaten Lampung Barat yang terdiri dari Pegawai Negeri Sipil (PNS) dan Pegawai Honorer (THLS) pada Dinas Pendidikan Kabupaten Lampung Barat berjumlah 86 (delapan puluh enam) orang.

b. Sampel

Sampel adalah bagian dari populasi yang menjadi sumber data dalam penelitian, jumlah populasi dalam penelitian ini adalah 86 (delapan puluh enam) orang pegawai yang ada pada Dinas Pendidikan di Kabupaten lampung Barat. Hal ini seperti yang dikemukakan oleh Suharsimi Arikunto (2006) bahwa, apabila subyeknya kurang dari 100, lebih baik diambil semua sehingga penelitian merupakan penelitian populasi.
Selanjutnya jika jumlah populasinya besar, dapat diambil antara 10-25\% atau 20-25\% atau lebih. Berdasarkan pendapat diatas maka sampel yang di ambil sebanyak 86 (delapan puluh enam) orang responden.

Setelah data terkumpul, maka langkah selanjutnya adalah mengolah data tersebut agar menjadi sebuah penelitan yang sempurna yaitu dengan langkah langkah sebagai berikut:

a. Editing, yaitu memeriksa data mengenai kelengkapan, kejelasan dan atau relevansinya dengan permasalahan yang sedang dibahas.

b. Coding, yaitu mengelompokkan jawaban yang telah terkumpul kedalam pokokpokok bahasan yang akan dilaksanakan sehingga memudahkan dalam proses penganalisaan.

c. Interpretasi data,yaitu mendeskrisikan data melalui tabel maupun narasi dan kemudian diinterpretasikan untuk dapat dianalisis dari hasil penelitian

d. Evaluating, yaitu mengevaluasi data untuk menjamin kebenaran.

Langkah selanjutnya adalah menganalisa data yang telah ada data terkumpul, dalam analisa data ini penulis menggunakan analisa data kualitatif dan data kuantitatif. Menurut Patton (2006) dalam Metodologi Penelitian Kualitatif, analisa data adalah proses mengatur urutan data, mengorganisasikannya ke dalam suatu pola, kategori, dan satuan uraian dasar. Ia membedakan penafsiran, yaiu memberikan arti yang signifikan terhadap analisa, menjelaskan pola uraian, dan mencari hubungan diantara dimensi-dimensi uraian.

Proses berjalannya analisa data kualitatif menurut Seidel, adalah senagai berikut: 
1. Mencatat yang menghasilkan catatan lapangan, dengan hal itu diberikan kode agar sumber datanya tetap dapat ditelusuri.

2. Mengumpulkan, memilah-milah, mengklarifikasi, mensintesiskan, membuat ikhtisar, dan membuat indeksnya.

3. Berfikir, dengan jalan membuat agar kategori data itu mempunyai makna, mencari dan menentukan pola dan hubungan-hubungan dan membuat temuan-temuan.

a. Data Kualitatif

Data Kualatif yaitu suatu data yang menggunakan uraian-uraian kata atau kalimat dengan membandingkan teoriteori dengan kenyataan yang ada di lapangan. Proses analisa merupakan proses untuk menemukan jawaban atas pernyataan tentang permasalahan yang dirumuskan dan diperoleh seiama penelitian. Adapun metode analisa data yang akan dipergunakan adalah metode analisa deskriptif kualitatif dengan teknik analisa persentase, yang didasarkan yang digunakan adalah:

$$
\begin{aligned}
& \mathrm{KP}=\mathrm{r}^{2} 100 \% \\
& \text { Dimana : } \\
& \mathrm{P}=\text { Persentase } \\
& \mathrm{F}=\text { Frekeeasi } \\
& \mathrm{N}=\text { Jumlah Frekuensi }
\end{aligned}
$$

Setelah diketahui frekuensi melalui rumus prosentase kemudian diolah dengan menggunakan tabel tunggal.

b. Data Kuantitatif
Untuk mempertegas hasil data kualitatif, maka diadakan pula analisa kuantitaif yakni analisa secara statistik dengan menerapkan rumus Korelasi Product Moment. Sehingga pada analisa ini dapat diketahui bagaimana pengaruh kualitas sumber daya manusia terhadap kinerja pegawai pada lingkup Dinas Pendidikan Kabupaten Lampung Barat.

Adapun rumus Korelasi Product Moment yang dipergunakan dalam penelitian ini adalah sebagai berikut:

$$
r_{x y}=\frac{N \sum X Y-\left(\sum X\right)\left(\sum Y\right)}{\sqrt{\left[N \sum X^{2}-\left(\sum X\right)^{2}\right]\left[N \sum Y^{2}-\left(\sum Y\right)^{2}\right]}}
$$

Keterangan:

$$
\begin{aligned}
& \text { rxy }=\text { Hubungan antara variabel } \mathrm{x} \text { dan } \mathrm{y} \\
& \mathrm{n}=\text { Banyak sampel } \\
& \mathrm{y}=\text { Hasil skor variabel terikat } \\
& \Sigma=\text { Jumlah } \\
& \mathrm{x}^{2}=\text { Hasil perkalian kuadrat dari skor } \\
& \text { angket variabel bebas } \\
& \mathrm{y}^{2}=\begin{array}{c}
\text { Hasil perkalian luadrat dari skor } \\
\text { angket variabel terikat }
\end{array}
\end{aligned}
$$

Dari perhitungan diatas, kemudian dikonsultasikan dengan skala interpretasi nilai $r$ untuk dapat mengetahui beberapa besarnya hubungan antara variabel bebas (x) dengan variabel terikat (y) tabel interpretasi tersebut adalah sebagai berikut:

Interpretasi Nilai $r$

\begin{tabular}{|c|l|}
\hline KATEGORI & KRITERIA \\
\hline $0,80-1,00$ & Sangat Tinggi \\
\hline $0,60-0,80$ & Tinggi \\
\hline
\end{tabular}




\begin{tabular}{|l|l|}
$0,40-0,60$ & Sedang \\
\hline $0,20-0,40$ & Rendah \\
\hline $0,00-0,20$ & Sangat Rendah \\
\hline
\end{tabular}

(Arikunto, 2006)

Sebelum data-data dimasukkan kedalam data statistik, maka angket tersebut dikumpulkan lalu ditabulasikan kedalam tabel dan setiap jawaban memiliki skor masing-masing :

- Alternatif jawaban Sangat Setuju (SS) diberi skor 5;

- Alternatif jawaban Setuju (S) diberi skor 4

- Alternatif jawaban Netral (S) diberi skor 3 ;

- Alternatif jawaban Tidak Setuju (TS) diberi skor 2;

- Alternatif jawaban Sangat Tidak Setuju (STS) diberi skor 1;

Untuk mengetahui besarnya pengaruh Kualitas Sumber Daya Manusia (x) terhadap Kinerja Pegawai (y) maka dipergunakan rumus uji hipotesis sebagai berikut :

$$
\mathrm{t}=\frac{r(n-2)}{\sqrt{1-r 2}}
$$

Dimana :

$$
\begin{aligned}
& \mathrm{t}=\text { Pengganti Koofesien Korelasi } \\
& \mathrm{r} \quad=\text { Koofesien Korelasi } \\
& \mathrm{n} \quad=\text { Jumlah Sampel }
\end{aligned}
$$

Sedangkan untuk pengujian hipotesis dalam penelitian ini, yaitu dengan melihat bagaimana hasil analisa, apabila hasil akhir analisa $\mathrm{t}$ hitung lebih besar dari $\mathrm{t}$ tabel, maka hipotesis diterima, begitu sebaliknya jika $t$ hitung lebih kecil dari t tabel, maka hipotesis ditolak.

\section{HASIL DAN PEMBAHASAN}

\section{Keadaan, Tugas Pokok dan Fumgsi}

a. Kedudukan

Dinas Pendidikan Kabupaten Lampung Barat merupakan unsur pelaksana pemerintah daerah dalam bidang pembangunan pendidikan yang berada di bawah dan bertangung jawab langsung kepada Bupati Kepala Daerah.

b. Tugas Pokok

Berdasarkan Peraturan Daerah Kabupaten Lampung Barat Nomor 13 Tahun 2008 tentang Pembentukan Organisasi dan Tata Kerja Dinas-dinas Daerah Kabupaten Lampung Barat, maka Dinas Pendidikan Kabupaten Lampung Barat mempunyai tugas pokok melaksanakan urusan pemerintahan daerah berdasarkan azas otonomi, dekonsentrasi dan tugas pembantuan di bidang pendidikan.

c. Fungsi

Untuk melaksanakan tugas pokok tersebut Dinas Pendidikan Kabupaten lampung Barat mempunyai fungsi :

a. Perencanaan dan perumusan kebijakan teknis di bidang pendidikan,

b. Penyelenggaraan urusan pemerintahan dan pelayanan umum di bidang pendidikan.

c. Pembinaan dan pelaksanaan tugas bidang pendidikan.

d. Pelaksanaan tugas lain yang diberikan oleh Bupati di bidang pendidikan.

\section{Analisis Data}

\section{Analisis Kualitatif}

Analisis kualitatif adalah suatu analisis dengan menggunakan suatu uraian-uraian yang berbentuk kalimat-kalimat dengan cara 
membandingkan teori-teori yang ada dengan kenyataan yang ada di lapangan (Hadi, 2003).

Sebelum penulis membahas lebih rinci masalah yang menjadi objek penelitian tentang pengaruh kualitas sumber daya manusia terhadap kinerja pegawai pada lingkup Dinas Pendidikan Kabupaten Lampung Barat, adapun untuk mencari interval pada setiap penelitian digunakan rumus interval sebagai berikut:

$$
\mathrm{I} \quad=\frac{N T-N R}{K}
$$

Keterangan:

$$
\begin{array}{ll}
\mathrm{I} & =\text { Interval } \\
\mathrm{NT} & =\text { Nilai Tertinggi NR Nilai Terendah } \\
\mathrm{K} & =\text { Kategori }
\end{array}
$$$$
\text { (Hadi, 2003) }
$$

Berdasarkan rumus tersebut, maka nilai interval untuk variabel bebas atau variabel $\mathrm{x}$ (Pengaruh Kualitas Sumber Daya Manusia) dapat diketahui dengan ketentuan sebagai berikut:

a. Total Skor Terendah

Skor terendah yang dicapai 86

Responden x 1 (Nilai Skor) = 86

Total Skor Rendah Skor rendah yang dicapai 86 Responden x 2 (Nilai Skor) $=172$

b. Total Skor Sedang

Skor sedang yang dicapai 86 Responden x 3 (Nilai Skor) $=258$

c. Total Skor Tinggi

Skor Tinggi yang dicapai 86 Responden $\mathrm{x} 4$ (Nilai Skor) $=344$

d. Total Skor Tertinggi

Skor tertinggi yang dicapai 86

Responden x 5 (Nilai Skor) $=430$

Kategori terdiri dari 5 (lima) kategori adalah :
- Alternatif jawaban Sangat Setuju (SS) diberi skor 5

- Alternatif jawaban Setuju (S) diberi skor 4

- Alternatif jawaban Netral $(\mathrm{N})$ diberi skor 3

- Alternatif jawaban Tidak Setuju (TS) diberi skor 2

- $\quad$ Alternatif jawaban Sangat Tidak Setuju (STS) diberi skor 1

Sehingga diperoleh nilai intervalnya yaitu :

$$
\begin{array}{ll}
\text { I } & =\frac{N T-N R}{K} \\
\text { I } & =\frac{430-86}{5} \\
\text { I } & =\frac{344}{5} \\
\text { I } & =68,8
\end{array}
$$

Dari interval tersebut diperoleh kategori yaitu

a. Kriteria Baik Sekali : 361,2 - 430

b. Kriteria Baik : 292,4-361,2

c. Kriteria Cukup Baik : 223,6 - 292,4

d. Kriteria Kurang Baik: 154,8 - 223,6

e. Kriteria Sangat Kurang Baik: 86 - 154,8

\section{Analisis Kuantitaif}

Berdasarkan metode pengumpulan data yang dilakukan melalui daftar pernyataan maka diharapkan dapat diketahui tingkat hubungan antara pengaruh sumber daya manusia (variabel $\mathrm{x}$ ) terhadap kinerja pegawai pada Dinas Pendidikan Kabupaten Lampung Barat (variabel y) dengan menggunakan rumus Korelasi Product Moment sebagai berikut : 


$$
r_{x y}=\frac{N \sum X Y-\left(\sum X\right)\left(\sum Y\right)}{\sqrt{\left[N \sum X^{2}-\left(\sum X\right)^{2}\right]\left[N \sum Y^{2}-\left(\sum Y\right)^{2}\right]}}
$$

Keterangan :

$\mathbf{r x y}=$ Koofesien Korelasi antara $\mathrm{x}$ dan $\mathrm{y}$

$\mathrm{x}=$ Nilai skor pengaruh Kualitas Sumber Daya Manusia

$\mathrm{y} \quad=$ Nilai Skor Kinerja Pegawai

$\mathrm{n} \quad$ = Besarnya sampai yang diambil

Berikut ini adalah tabel hasil perhitungan yang diperoleh dari jawaban responden melalui angket yang disebarkan, diketahui:

$$
\begin{aligned}
& N=86 \\
& \Sigma x=2540 \\
& \Sigma y=2298 \\
& \Sigma y^{2}=63962 \\
& \Sigma x y=69452
\end{aligned}
$$

Dan langkah selanjutnya adalah memasukan nilai-nilai diatas kedalam rumus Product Moment, jadi bila dimasukkan kedalaman rumus akan didapat perhitungan sebagai berikut :

$$
\begin{aligned}
& r_{x y}=\frac{N \sum X Y-\left(\sum X\right)\left(\sum Y\right)}{\sqrt{\left[N \sum X^{2}-\left(\sum X\right)^{2}\right]\left[N \sum Y^{2}-\left(\sum Y\right)^{2}\right]}} \\
& \mathbf{r x y}= \\
& \frac{86(69452)-(2540) \cdot(2298)}{\sqrt{\left\{86.78910-(2540)^{2}\right\} \cdot\left\{86.63962-(2298)^{2}\right\}}} \\
& \mathbf{r x y}=\frac{86(694522)-(2540) \cdot(2298)}{\sqrt{\left\{86.78910-(2540)^{2}\right\}}}
\end{aligned}
$$

$$
\begin{aligned}
& \begin{array}{l}
\text { rxy } \\
= \\
\frac{5972872-58369820}{\sqrt{\{6786260-6451600\}} \cdot\{5500732-5280804\}}
\end{array}
\end{aligned}
$$

$$
\begin{aligned}
& \mathbf{r x y}=\frac{135952}{\sqrt{73601104480}} \\
& \mathbf{r x y}=\frac{135953}{271295,2349} \\
& \mathbf{r x y}=\mathbf{0 , 5 0 1}
\end{aligned}
$$

Berdasarkan hasil perhitungan, maka didapat untuk $r$ hitung adalah 0,501 Apabila dikonsultasikan dengan $\mathrm{r}$ tabel untuk taraf signifikan 5\% adalah 0,213 Ternyata $r$ hitung lebih besar daripada tabel atau :

$\mathrm{r}$ hitung $(0,501>\mathrm{r}$ tabel $(0,213)$ pada taraf signifikan $5 \%$

Dengan demikian kualitas sumber daya manusia mempunyai pengaruh yang positif terhadap kinerja pegawai pada Dinas Pendidikan Kabupaten Lampung Barat.

Untuk mengetahui bagaimana interprestasi hubungan antara kualitas sumber daya manusia terhadap kinerja pegawai pada dinas Pendidikan Kabupaten Lampung Barat, maka nilai rhitung jika dikonsultasikan dengan daftar interprestasi berada diantara nilai $0,300,0,700$ yang berarti interprestasi ini masuk dalam kategori cukup atau sedang, sedangkan untuk mengetahui kadar persentase dari pengaruh kualitas sumber daya manusia terhadap kinerja pegawai pada Dinas Pendidikan Kabupaten Lampung Barat, penulis menggunakan rumus :

$$
\begin{aligned}
\mathrm{KP} & =r^{2} \times 100 \% \\
& =0,501^{2} \times 100 \% \\
& =0,251 \times 100 \%
\end{aligned}
$$




$$
=25,1 \%
$$

Dari perhitungan di atas dapat ditarik suatu kesimpulan bahwa pengaruh kualitas sumber daya manusia terhadap kinerja pegawai pada Dinas Pendidikan Kabupaten Lampung Barat, yaitu sebesar 25,1,2\% sedangkan 74,9\% dipengaruhi oleh faktor-faktor lain. Hal ini dikarenakan kualitas sumber daya manusia saja tidak cukup untuk meningkatkan kinerja pegawai pada Dinas Pendidikan Kabupaten Pendidikan Lampung Barat, tetapi juga dibutuhkan faktor penujang lainnya, seperti pendidikan dan pelatihan dalam peningkatan kemampuan pegawai untuk bidang keahlian tertentu, fasilitas kerja, pengalaman, kreativitas, tanggung jawab, kerjasama dan hal-hal lainnya, terkadang kondisi kultur ataupun keadaan juga sangat mempengruhi suatu kinerja pegawai.

Selanjutnya untuk menguji hipotesis yang penulis ajukan, maka rumus yang digunakan melalui uji tes dengan rumus :

$$
\mathrm{t}=\frac{r \sqrt{(n-2)}}{\sqrt{1}-r 2)}
$$

Keterangan

$$
\begin{aligned}
\mathrm{t} & =\text { Pengganti Koofesien Korelasi } \\
\mathrm{r} & =\text { Koofesien Korelasi } \\
\mathrm{n} & \quad=\text { Jumlah Sampel } \\
\mathrm{t} & =\frac{0,501 \cdot \sqrt{(86-2)}}{\sqrt{1}-0,501^{2}} \\
\mathrm{t} & =\frac{4,592832881}{0,8653} \\
\mathbf{t} & =\mathbf{5 , 3 0 8}
\end{aligned}
$$

Setelah didapat hasil di perhitungan $\mathrm{t}$ test kemudian dikonsultasikan dengan $\mathrm{t}$ tabel pada taraf nyata dengan $\mathrm{dk}=\mathrm{n}=2$ dan $\mathrm{a}=0,05$ yaitu :

$$
\begin{aligned}
\text { T tabel } & =\mathrm{t}(1-\mathrm{a})(\mathrm{n}-2) \\
& =\mathrm{t}(1-0,05)(86-2) \\
& =\mathrm{t}(0,95) \cdot(84) \\
& =1,67
\end{aligned}
$$

(dalam tabel distribusi normal)

Kriteria pengujian adalah sebagai berikut:

a. Ho diterima jika hitung > tabel dengan derajat kebebasan $(\mathrm{dk})=(\mathrm{n}-2)$ dan $\mathrm{a}=0,05$

b. Ha ditolak jika hitung < tabel dengan derajat kebebasan $(\mathrm{dk})=(\mathrm{n}-2)$ dan $\mathrm{a}=$ 0,05

Dari analisa data diperoleh hitungan lebih besar dari tabel yaitu hitung $(5,308)>$ tabel $(1,67)$ yang berarti memenuhi kriteria Ho diterima. Dengan demikian terbukti bahwa ada pengaruh Kualitas Sumber Daya Manusia terhadap Kinerja Pegawai pada Dinas Pendidikan Kabupaten Lampung Barat.

\section{KESIMPULAN DAN SARAN}

\section{Kesimpulan}

Berdasarkan hasil penelitian yang telah dilaksankan, maka dapat diambil suatu kesimpulan sebagai berikut :

1. Kualitas sumber daya manusia berpengaruh pada kategori sedang atau cukup terhadap kinerja pegawai pada Dinas Pendidikan Kabupaten Lampung Barat. Hal ini dikarenakan kualitas sumber daya manusia saja tidak cukup untuk menunjang keberhasilan kinerja pegawai 
pada Dinas Pendidikan Kabupaten

Lampung Barat. tetapi juga dibutuhkan fakto-faktor lainnya seperti kelengkapan kantor, fasilitas yang ada seperti komputer, jaringan ICT (Information and Communicaion Technologies) atau pun hal lainnya yang dapat menciptakan kenyamanan dalam bekerja, terkadang kondisi kultur ataupun kebiasaan pegawai juga sangat mempengaruhi keberhasilan kinerja pegawai pada Dinas Pendidikan Kabupaten Lampung Barat.

2. Berdasarkan hasil perhitungan, maka didapat untuk $\mathrm{r}$ hitung adalah 0,501. Apabila dikonsultasikan dengan $\mathrm{r}$ tabel untuk taraf signifikan 5\% adalah 0,213. Ternyata $r$ hitung lebih besar dari pada $r$ tabel atau $r$ hitung $(0,501)>r$ tabel (0.213) pada taraf signifikan 5\%, dengan demikian kualitas sumber daya manusia mempunyai pengaruh yang positif terhadap kinerja pegawai pada Dinas Pendidikan Kabupaten Lampung Barat.

3. Kadar persentase pengaruh kualitas sumber daya manusia terhadap kinerja pegawai pada Dinas Pendidikan Kabupaten Lampung Barat, yaitu scbesar $25,1 \%$ sedangkan $74,9 \%$ dipengaruhi oleh faktor-faktor lain, seperti kelengkapan kantor, fasilitas yang ada seperti komputer, jaringan ICT (Information and Communicaion Technologies) atau pun hal lainnya yang dapat menciptakan kenyamanan dalam bekerja.

\section{Saran}

1. Penambahan kelengkapan dan fasilitas kantor sangat diharapkan oleh seluruh staf pegawai Dinas Pendidikan Kabupaten Lampung Barat untuk memperlancar dan mempermudah dalam penyelesaian tugas dan pekerjaan yang telah diberikan oleh pimpinan.

2. Peningkatan kualitas sumber daya manusia pada Dinas Pendidikan Kabupaten Lampung Barat sangat diperlukan untuk menambah wawasan dan keahlian dalam bidang tertentu guna memperlancar penyelesaian tugas yang dihadapi setiap harinya.

3. Lebih di tingkatkan lagi kedisiplinan, tanggung jawab dan kerjasama dengan rekan kerja dalam penyelesaian tugas dan pekerjaan pada Dinas Pendidikan Kabupaten Lampung Barat.

\section{DAFTAR PUSTAKA}

Anwar Prabu Mangkunegara, 2008. Manajemen Sumber Daya manusia Perusahaan. Bandung: Rosda.

Arikunto, Suharsimi, Prosedur Penelitian : Suatu Pendekatan Praktik, Edisi Revisi VI, Jakarta: PT Rineka Cipta, 2006.

Departemen Pendidikan Nasional. 2002. Kamus Besar Bahasa Indonesia, Jilid III .Jakarta: Balai Pustaka.

Hadi, Sutrisno. 2003. Metodologi Research. Yogyakarta: Pustaka Andi.

Husein, Umar. 2005. Riset Sumber Daya Manusia Dalam Organisasi. Edisi Revisi. Jakarta: PT. Gramedia Pustaka Utama.

Patton, Michael Quinn. 2006. Metode Evaluasi Kualitatif. Yogyakarta: Pustaka Pelajar. 
Peraturan Daerah Kabupaten Lampung Barat Nomor 13 Tahun 2008 tentang Pembentukan Organisasi dan Tata Kerja Dinas-dinas Daerah Kabupaten Lampung Barat.

Ridwan. 2004. Metode dan Teknik Penelitian. Alfabeta. Bandung.

Seidel, V., 2006, Initial and Bulk Extraction, In: Sarker, S. D., Latif, Z., \& Gray, A. I., (eds) Natural Product Isolation, 27-46, Humana Pers, New Jersey.
Singarimbun, Masri dan Sofian Effendi, Metode Penelitian Survei, Jakarta: LP3ES, 2008.

Undang-Undang Nomor 20 Tahun 2003 tentang Sistem Pendidikan Nasional.

Winarno, Surakhmad. 2004. Pengantar Penelitian Ilmiah, Dasar, Metode, dan Teknik. Bandung: Tarsito.

Wood at al.2001. Organizational Behavior An Asia Pacific Perspective. First Edition. John Willey \& Sons. USA. 